\title{
Cinnamon Extract Effects on Insulin Resistance, Metabolic Factors, and Menstrual Cyclicity for Women with Polycystic Ovary Syndrome: A Systematic review and Meta-Analysis
}

\author{
Riska Wahyuningtyas ${ }^{1}$ and Ashon Sa'adi ${ }^{1}$ \\ ${ }^{1}$ Universitas Airlangga Fakultas Kedokteran
}

October 14,2020

\begin{abstract}
Cinnamon is herbal medicine supposed to improve metabolic disorder of PCOS. This study investigated the effects of cinnamon extract effect on insulin resistance, metabolic factors, and menstrual cyclicity for woman with PCOS. This is systematic review and meta-analysis of randomized controlled trials (RCTs). We searched the MEDLINE, Cochrane, Google Scholar, and Pubmed databases to identify relevant studies using cinnamon extract for PCOS. Five RCTs consisting 206 women were entered in the meta-analysis. Significant differences in body mass index (mean difference (MD) $=-0.21,95 \%$ CI:-1.80 to $1.38, \mathrm{p}=0.79 ; 143$ participants), weight $(\mathrm{MD}=1.08,95 \% \mathrm{CI}:-2.79$ to $4.96, \mathrm{p}=0.58 ; 143$ participants), insulin resistance $(\mathrm{MD}=-0.19,95 \% \mathrm{CI}$ : -0.54 to $0.15, \mathrm{p}=0.27,190$ participants), fasting blood glucose ( $\mathrm{MD}=-4.8,95 \% \mathrm{CI}$ : -8.04 to $-1.57, \mathrm{p}=0.004 ; 143$ participants), trygliceride ( $\mathrm{MD}=-10.73,95 \% \mathrm{CI}:-26.35$ to $4.88, \mathrm{p}=0.18 ; 143$ participants), LDL-cholesterol $(\mathrm{MD}=-3.39,95 \% \mathrm{CI}:-12.27$ to $5.50, \mathrm{p}=0.46 ; 143$ participants), HDL-cholesterol $(\mathrm{MD}=-27.24,95 \% \mathrm{CI}:-32.62$ to $-21.85, \mathrm{p}<0.00001 ; 143$ participants), total cholesterol ( $\mathrm{MD}=-7.8,95 \% \mathrm{CI}:-17.48$ to $1.89, \mathrm{p}=0.11 ; 143$ participants), insulin ( $\mathrm{MD}=-2.20,95 \%$ CI: -4.17 to -0.23 , $\mathrm{p}=0.03$; 143 participants), DHEA level ( $\mathrm{MD}=-0.1,95 \% \mathrm{CI}:-0.62$ to $0.41, \mathrm{p}=0.70 ; 104$ participants), and menstrual cyclicity in 6 months $(\mathrm{MD}=2.28,95 \% \mathrm{CI}: 1.83$ to $2.73, \mathrm{p}<0.00001 ; 33$ participants) were obtained. Cinnamon can be a potential supplementary therapy agent for PCOS women as it improves fasting blood glucose, insulin level, HDL-cholesterol and menstrual cyclicity in PCOS women.
\end{abstract}

\section{Hosted file}

full manuscript.pdf available at https://authorea.com/users/367260/articles/486739-cinnamonextract-effects-on-insulin-resistance-metabolic-factors-and-menstrual-cyclicity-forwomen-with-polycystic-ovary-syndrome-a-systematic-review-and-meta-analysis 